\title{
THE EFFECT OF SYNTHETIC OXYTOCIN UPON SEMINAL CHARACTERISTICS AND SEXUAL BEHAVIOUR IN MALE RABBITS
}

\author{
D. FJELLSTRÖM, J. E. KIHLSTRÖM AND P. MELIN \\ Institute of Zoophysiology, Uppsala, Sweden
}

(Received 24th April 1968)

In male rabbits the composition of the ejaculate changes, and the willingness to copulate increases upon intravenous injection of purified extract of the posterior lobe of the pituitary (Kihlström \& Melin, 1963; Melin \& Kihlström, 1963). These effects were ascribed to the oxytocic activity of the extract which, however, may contain small amounts of other hormones as impurities. For this reason the experiments have been repeated, using synthetic oxytocin (Syntocinon, Sandoz).

Eight sexually mature rabbits of the Bourgogne breed, none of them more than 2 years old, were studied from 10th February to 27th May. The bucks were kept in individual cages throughout the experimental period and were all given the same kind of food once a day at a given time. The temperature in the animal house varied between +16 and $+18^{\circ} \mathrm{C}$. Before the start of the experiments the animals were accustomed to the experimental procedures as described earlier (Kihlström \& Melin, 1963; Melin \& Kihlström, 1963), trained to ejaculate into an artificial vagina covered with fur, and the quality of their semen examined. The experiments were always performed between 07.00 and 08.00 hours before the start of the daily routine in the animal house.

The injections of synthetic oxytocin were given in the marginal vein of the ear, the dose being 0.30 i.u. $/ \mathrm{kg}$ body weight. Physiological saline was used for control injections, each animal serving as its own control. The seminal volumes obtained during the control experiments did not differ from those obtained from the same animals before the beginning of the experiments.

The sexual drive was estimated in the following way. Thirty seconds after the injection the artificial vagina was presented to the animal. The buck could then ejaculate repeatedly for $30 \mathrm{~min}$ (exhaustion test). The time between the presentation of the vagina and the first ejaculation (the reaction time) was measured with a stop watch. The length of this time as well as the number of ejaculates during the exhaustion test were taken as expressing the intensity of the sexual drive. Each ejaculate was collected separately into a small graduated and calibrated test tube, used in determining the yielded volume.

Ejaculates containing a gelatinous mass were noted, and the mass removed by means of a glass spatula. The concentration of sperm cells was determined with an electronic cell-counter (Celloscope 202 Lars Ljungberg \& Co. Ltd, Stockholm) according to the method described by Kihlström \& Fjellström (1967). 
The 'male sexual cycle' (for a review, see Kihlström, 1966), manifesting itself for instance as a cyclic variation in the ejaculate volume, the interval between two successive peaks in the volume being 5 to 6 days, was determined as previously described (Kihlström \& Melin, 1963; Melin \& Kihlström, 1963). Four animals were injected the day after a peak in ejaculate volume, four more the day after a minimum volume. Each buck was given four injections of oxytocin and the same number of control injections. One ejaculate heavily contaminated with urine has been excluded from the statistical treatment.

TABLE 1

COMPARISON BETWEEN SEMINAL GHARACTERISTICS OF THE FIRST EJAGULATES IN EXHAUSTION EXPERIMENTS

\begin{tabular}{l|c|c|c|c}
\hline & $\begin{array}{c}\text { Control } \\
\text { injections } \\
(n=32)\end{array}$ & $\begin{array}{c}\text { Hormone } \\
\text { injections } \\
(n=31)\end{array}$ & $t$ & $P<$ \\
\hline Volume $(\mathrm{ml})$ & $\begin{array}{c}0 \cdot 33 \pm 0.02 \\
158 \pm 17 \\
54 \pm 6\end{array}$ & $\begin{array}{c}0 \cdot 49 \pm 0.03 \\
171 \pm 18 \\
88 \pm 12\end{array}$ & $\begin{array}{c}5 \cdot 23 \\
0 \cdot 50 \\
\text { Sperm cells }\left(\times 10^{6}\right) / \mathrm{ml}\end{array}$ & $\begin{array}{l}0.001 \\
0.7 \\
\text { Sperm cells }\left(\times 10^{6}\right) / \text { ejaculate }\end{array}$ \\
\hline
\end{tabular}

TABLE 2

COMPARISON BETWEEN SEMINAL GHARAGTERISTICS OF EJAGULATES NUMBERS 2 TO 5 IN EXHAUSTION EXPERIMENTS

\begin{tabular}{|c|c|c|c|c|}
\hline & $\begin{array}{c}\text { Control } \\
\text { injections } \\
(n=32)\end{array}$ & $\begin{array}{l}\text { Hormone } \\
\text { injections } \\
(n=31)\end{array}$ & $t$ & $P<$ \\
\hline $\begin{array}{l}\text { Volume }(\mathrm{ml}) \\
\text { Sperm cells }\left(\times 10^{6}\right) / \mathrm{ml} \\
\text { Sperm cells }\left(\times 10^{6}\right) / \text { ejaculate }\end{array}$ & $\begin{array}{l}0 \cdot 12 \pm 0 \cdot 01 \\
221 \pm 16 \\
42 \pm 5\end{array}$ & $\begin{array}{c}0 \cdot 14 \pm 0 \cdot 01 \\
348 \pm 34 \\
67 \pm 9\end{array}$ & $\begin{array}{l}0 \cdot 01 \\
2 \cdot 59 \\
2 \cdot 38\end{array}$ & $\begin{array}{l}0 . \overline{01} \\
0.01\end{array}$ \\
\hline
\end{tabular}

TABLE 3

EFFEGTS OF OXYTOCIN ON THE EJAGULATORY PERFORMANCE OF RABBITS DURING EXHAUSTION EXPERIMENTS

\begin{tabular}{l|c|c|c|c}
\hline & $\begin{array}{c}\text { Control } \\
\text { injections } \\
(n=32)\end{array}$ & $\begin{array}{c}\text { Hormone } \\
\text { injections } \\
(n=31)\end{array}$ & $t$ & $P<$ \\
\hline $\begin{array}{l}\text { Reaction time (seconds) } \\
\text { No. of ejaculates }\end{array}$ & $\begin{array}{c}35.9 \pm 1 \cdot 8 \\
6.6 \pm 0.06\end{array}$ & $\begin{array}{c}27 \cdot 2 \pm 1 \cdot 6 \\
8.3 \pm 0.06\end{array}$ & $\begin{array}{c}3 \cdot 65 \\
6 \cdot 13\end{array}$ & $\begin{array}{c}0.001 \\
0.001\end{array}$ \\
\hline
\end{tabular}

As seen from Table 1, oxytocin significantly increases the volume of the first ejaculate obtained during the exhaustion test. The total number of sperm cells also rises, but not the number of cells per $\mathrm{ml}$. The increasing volume, therefore, probably depends mainly upon an increasing amount of secretions from the accessory glands.

The volumes of ejaculates Nos. 2 to 5 in the series yielded after injections of oxytocin do not differ from those following injections of sodium chloride 
(Table 2). After injections of oxytocin, however, the numbers of sperm cells per $\mathrm{ml}$ as well as per ejaculate, increase significantly (Table 2). Twenty-four hours after injections of oxytocin gelatinous masses appeared significantly more often than $24 \mathrm{hr}$ after injections of physiological saline $\left(\chi^{1}=4.68, P<0.05\right)$.

The number of ejaculates collected during the exhaustion test rose significantly after injections of oxytocin, and the reaction time exhibited a significant drop (Table 3).

In the present material no difference in the response between animals receiving injections in different phases of the male sexual cycle could be detected. With this exception, however, the present results confirm those previously obtained (Kihlström \& Melin, 1963). Thus the observed effect must be ascribed to the action of oxytocin.

According to our results, the immediate effects of oxytocin are a higher motivation for copulation and an increased output of fluid from the accessory glands. Simultaneously, or possibly somewhat later, the effectiveness of the transport of sperm cells in the genital ducts is increased.

Increasing numbers of spermatozoa in the ejaculates after injections of oxytocin have been reported also for rams (Ewy \& Bielanski, 1962) and, together with increasing volumes of the ejaculates, for bulls (Beresnev, 1963).

These observations conform to the theory that the contractile mechanisms involved in the transport of spermatozoa are partly regulated by oxytocin (Cross \& Glover, 1958).

\section{REFERENCES}

Beresnev, P. (1963) The effect of oxytocin and a neurotropic preparation on bull semen. (In Russian.) Zhivotnovodstvo, 25, 68.

Cross, B. A. \& Glover, T. D. (1958) The hypothalamus and seminal emission. F. Endocr. 16, 385.

EwY, Z. \& BIELANSKI, W. (1962) Influence of oxytocin on spermatozoa transport in the ductus deferens of the ram. Proc. Inter. Union Physiol. Sci. XXIInd Inter. Congress, Leiden, 2, No. 545.

Кiнцsтröм, J. E. (1966) A sex cycle in the male. Experientia, 22, 630.

Kinlström, J. E. \& FJellström, D. (1967) Automatic counting of spermatozoa in rabbit semen. $\mathcal{F}$. Reprod. Fert. 14, 155.

Kinlström, J. E. \& Melin, P. (1963) The influence of oxytocin upon some seminal characteristics in the rabbit. Acta physiol. scand. 59, 363.

Melin, P. \& Kinlström, J. E. (1963) The influence of oxytocin on sexual behaviour in male rabbits. Endocrinology, 73, 433. 